\title{
The Life Cycle of Synchytrium pogostemonis on Pogostemon cablin
}

\author{
DONO WAHYUNO \\ Indonesia Medicinal and Aromatic Crops Research Institute, Departemen Pertanian Indonesia, \\ Jalan Tentara Pelajar No. 3, Bogor 16111, Indonesia \\ Phone:+62-251-8321879, Fax:+62-251-8327010,Email:dwahyuno@yahoo.ca
}

\begin{abstract}
Synchytrium pogostemonis became a serious disease of patchouli cultivation in Indonesia, since it spread widely in many patchouli producing areas in Indonesia. The fungus caused warts on leaves, petioles and young stems of infected patchouli. The infected plant developed rosette habit, lost its vigour, was susceptible to drought period and finally died. Few information regarding the eco-biology and life cycle of the fungus were available The present research aimed at describing the life cycle of S. pogostemonis. The diseased patchouli was obtained through artificial inoculation. Mass inoculation was carried out by placing the healthy patchouli seedling close to diseased patchouli as source of inoculum and was watered regularly using the top head sprinkler. The infected leaves were observed both under disecting and light compound microscopes, and the existing fungal structure were recorded, described and measured. It was observed that S. pogostemonis is a long-cycle type fungus, the sexual reproduction was initiated by zoospores, followed subsequently by development of resting-structure spores, vesicles, sori, and sporangial formation.
\end{abstract}

Key words: Synchytrium, Pogostemon cablin, life cycle

Patchouli (Pogostemon cablin) is a patchouli-oil producing plant species, which is an important source of income for many farmers in Indonesia. Recently pest and diseases has become a serious constraint in patchouli cultivation, including Ralstonia solanacearum, viruses and nematodes. In the last three years, a disease named budok (wart in local language) has spread widely in patchouli production centres in Indonesia. The warts appeared on leaves, petioles, young stems, and young shoots (Fig 1A). The disease was believed to be caused by virus or micoplasm-like organisms as indicated by their typical symptom appearances, such as leave curl and rosetting (Sitepu and Asman 1991; Mustika and Asman 2004). However, detailed observation on diseased plants collected from various patchouli plantations in Indonesia, the resting spore of the biotrophic fungus Synchytrium was noticed consistenly from the samples (Wahyuno et al. 2007). Artificial inoculation experiment indicated that the presence of water film on soil particles was favourable for fungus spreading and infection development (Fig 1B). Based on the existing morphological characteristics of the fungus, it is identified as Synchytrium pogostemonis (Wahyuno and Sukamto 2010). The same species was also reported occuring in India (Dayal 1997) and its world wide distribution was still limited to South Asia and South East Asia (Thronton 2002), where patchouli plants have been widely cultivated.

Up to now there is still limited information regarding the life cycle of S. pogostemonis. Karling $(1954,1964)$ in his compilation of Synchytrium world wide did not mention the occurence of S. pogostemonis; and there were various life cycle types in Synchytrium (Karling 1964; Webster 1988). The objective of the present study is to find out the life cycle of S. pogostemonis with the final objective of controlling the disease in the future.

\section{MATERIALS AND METHODS}

The diseased patchouli plants studied were obtained and propagated by artificial inoculation. The diseased patchouli plants collected from Bogor (Syn-TRO-01) and Kuningan in West Java (Syn-TRO-03) were used as source of inoculums. The inoculation was conducted by placing infected leaves, petioles and young stems around the bases stems of 4-node young patchouli cuttings planted in polybags (Wahyuno and Sukamto 2010). The inoculated patchouli cuttings were incubated in the green house for about one month until the warts appeared on stems, petioles or leaves. During this period, watering the soil was carried out to maintain high humidity to create a suitable condition for the infection of the zoospores of S. pogostemonis. Mass inoculation was carried out to obtain sufficient amounts of diseased patchouli cuttings by placing the healthy patchouli cuttings around those infected cuttings, obtained from previous artificial inoculation Over head watering by sprinkle spraying was carried out daily to enhance the occurrence of mass infection of patchouli cuttings.

The infected leaves were characterized by the presence of warts on its either abaxail or adaxial surfaces. Prior to the observation under compound microscope, the leaf tissues were softened, using the modified method of Rao and Pavgi (1986), by adding a soaking treatment in sodium hyphoclorite solution before the leaf tissues were soaked in sterilized water. The infected leaves were cut into pieces of about $1 \mathrm{~cm}^{2}$ each, which were then soaked in a $1 \%$ sodium hypochlorite solution for one minute, rinsed with sterilized water and finally incubated in sterilized water in a botle for two days. Under a dissecting microscope slide preparation was made from softened pieces of leaves and the slides were then observed under a compound microscope. The existing structures of Synchytrium were recorded, measured and characterized. The existing fungal structures were categorized and named according to the system proposed by Karling (1964). 


\section{RESULTS}

Warts appeared on the surface of stems and newly developed shoots as well as leaves on stems arising from below the soil surface. The wart formation tended to develop more toward the younger upper part of the plant than toward the older base of the stem. Thus the warts on the lower sections of the stems were older than those on the upper parts. The old warts were characterized by the presence of yellow resting spores inside which could be easily observed by using a hand lens.

Observations, with a light microscope, of cells around the warts revealed that the cells contained granulle-like structures inside (Fig 1C). Such structures were not observed in uninfected leaves. The fungal thalli were not presemt in the cells of infected plant leaf tissues.

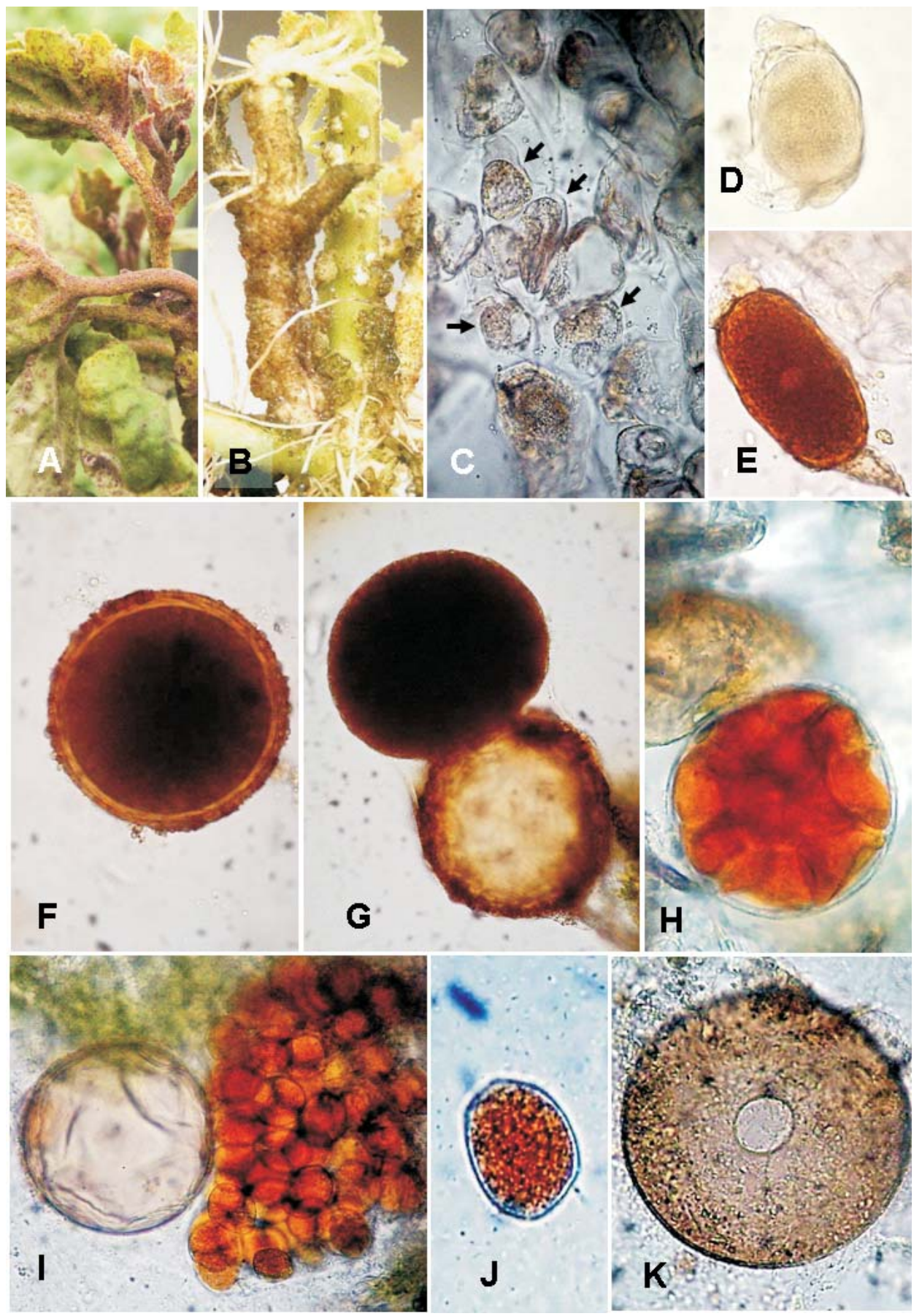

Fig 1 Symptoms and resting spore developmental stages of Spogostemonis. (A) Advanced symptom, with warts on young stems, leaves and petioles, (B) Warts on artificially inoculated stems, (C) summer spores (sporangia) inside the infected plant cells ( ), (D) An imature resting spore, (E) An advanced stage of imature resting spore, (F) A mature resting spore, $(\mathrm{G})$ A vesicle is emerging from a resting spore (resting spore functions as prosorus), (H) Cell division forming sporangia within a vesicle which functioned as a sorus, (I) Broken sorus liberating the sporangia, leaving the resting spore empty (J) Individual sporangium of a sorus emerged from a resting spore, and $(\mathrm{K})$ An empty resting spore with conical releasing pore as seen from top view. 
Further observations on the infected plants showed that resting spores (winter spores) of Synchytrium were noted in warty leaf tissue. The yellow to light orange or light brown resting spores with thick cell wall were generally recognizable inside enllarged plant cells. The immature resting spores were ellipsoid, oblong to globose, and the nucleus could be identified inside the spore as hyaline spot (Fig 1D, 1E), while but mature-resting spores were generally oblong, light orange to dark brown, having rough surfaces, with diameter range of 70.0-(106.7)-150.0 $\mu \mathrm{m}$ (Fig 1F). The number of resting spores within a single wart varies from 1 to 11 , depending on the size of the warts. Vesicle-like structures could be identified in some resting spores, whose size was about the same as that of the resting spores (Fig 1G). Each vesicle contained 2035 , yellow-orange sporangia. In some other vesicles, the yellow-orange sporangia were hyaline, thin-walled oblong to globose or irregular, with size range of 25.0(29.7)-35.0 x 17.5-(24.9)-30.0 $\mu \mathrm{m}$ (Fig 1H, 1I and 1J). The empty resting spores were also noted and some of them had conical releasing pores (Fig $1 \mathrm{~K}$ ). In the observed samples, the true fungal thalli were not noted in this stage.

\section{DISCUSSION}

Present microscopic observations indicated that the summer sporangia (the asexual reproductive sporangia) did exist in nature. The summer sporangia were present as granulle-like structures inside of the infected leaves. It was not easy to fnd and identify the summer sporangia in the warts, even the samples were soaked in distilled water prior to observations under a light microscope.

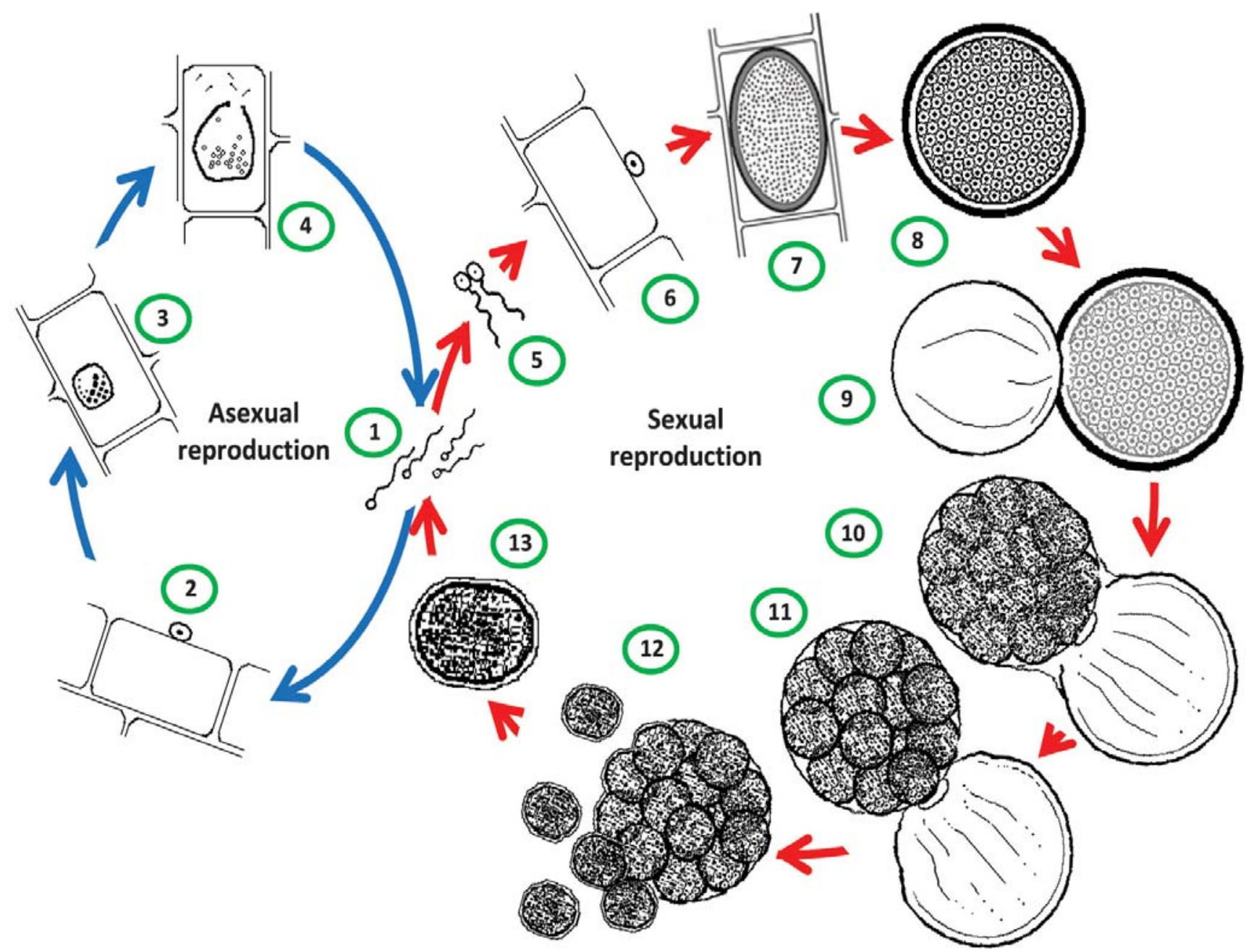

Fig 2 The life cycle of Synchytrium pogostemonis. (1) Zoospores, (2) encysting and ingression of the zoospore into a healthy plant cell, (3) summer sporangia in an infected plant cell, (4) sporangium liberates zoospores, (5) mating of two different type of zoospores, (6) encysting and ingression of the mating zoospores into healthy plant's cell, (7) young resting spore inside a plant cell, (8) a mature resting spore, (9) vesicle formation, (10) the vesicle transforms into a sorus with initial formation of sporangia, (11) further stage of sorus development, (12) a sorus breaks and releases the sporangia, (13) single sporangium and the life cycle repeated by liberating the zoospores. 
The microscopic observation sugested that the asexual cycle of $S$. pogostemonis initiated by liberation of zoospores from summer sporangia.and the liberated zoospores swam to the surrounding cells. They. were then encysting on the plant cells and eventually they infected the plant cells (Fig 2.1, 2.2, and 2.3). In the subsequent stage the summer sporangia were formed within the plant cells. The mature summer sporangia released the zoospores into adjacent cells or on to plant surfaces in searching for other healthy plant cells, and the asexual cycle was repeated (Fig 2.4). The zoospore dispersal through water movement or water film seemed more prevalent than dispersal by wind. Artificial inoculation experiment on patchouli seedlings with water as a planting medium was successfully conducted in a green house (Wahyuno and Sukamto 2010). It sugested that summer spores of Synchytrium desmodii were naturally dispersed by water movement, water splash or movement within cells of wartz but not by wind as dry spores (Price 1987).

The present study indicated also that $S$. pogostemonis had a macrocylic life cycle. The presence of orange to light brown and thick walled spores inside the warts was a clear evidence of the existence of the resting spores. The resting spore is an indicator of the sexual reproduction occurring in nature. The resting spores are the product of pairing of two different types of zoospores (Fig 2.5), encysting and adhering on plant cells prior to infecting (Fig 2.6), developing young resting spores (Fig 2.7) and formation of mature resting spores (Fig 2.8). A resting spore germinates by producing a vesicle-like structure without rupturing the resting spore cell wall, but by emerging through the conical structure which is a part of the resting spore, as the releasing pore (Fig 2.9). In this stage the resting spore functions as prosorus. The vesicle-like structure acts as a sorus where initial formation of a sporangial structure takes place (Fig 2.10). Further cleavage continues to take place in the sori, leading to the advanced stage of sporangial formation (Fig 2.11). In the advanced stage, the sorus tears its thin cell wall, and release the sporangia into soils or plant surfaces (Fig 2.12 and 2.13), followed by liberating the zoospores from the sporangia, and the sexual reproduction cycle is repeated.

The result of present observation differs from that reported by Dayal (1997), who shows that the vesicle-like structures emerge from sori, instead of resting spores. Karling (1964) points out that the presence of conical pore of empty sheath is an indicator of the presence of prosorial stage in the life cycle of Synchytrium. The resting spore of Synchytrium the product of mating of two different types of zoospore (Karling 1964; Garcia-Massini 2007), especially when the environment is unfavorable (Hoffman et al. 2008).

Based on the current observation, it is inferred that $S$. pogostemonis infecting $P$. cablin belongs to the long lifecycle type, and this phenomenon is reported for the first time in the present study. Therefore, S. pogostemonis suppose belongs to member of the subgenus Mycrosynchytrium. Karling (1964) proposed Synchytrium to consist of six subgenera, i.e. Mycrosynchytrium, Mesochytrium, Synchytrium, Exosynchytrium, Pycnochytrium, and
Woroninella. Mycrosynchytrium is characterized by its long life-cycle, the presence of prosori, sori, sporangia zoospores and resting spore stages, as well as the nature of its resting spore that do not function as sporangia (Karling 1964). The life-cycle of $S$. pogostemonis differs from $S$. endobioticum infecting potatoes. At the sexual reproductive cycle stage, the resting spore of $S$. endobioticum transforms its function to become the sporangium without passing through either prosori nor sorial stage (Mesochytrium sub genus) (Karling 1964). In P. cablin the warts appeared at the stem bases and young shoots emerging from the below soil surface three to four weeks after artificial inoculation (Wahyuno and Sukamto 2010); and one to weeks if the inoculation were carried out on leaves (Sukamto and Wahyuno 2008). On winged bean, warts appeared one week after leaves were inoculated with Synchytrium psophocarpi (Karami et al. 2009). Lange and Olson (1981) mentioned that the warts were seen developing at the base of the potato plants three to four weeks after artificial inoculation. Garcia-Massini (2007) pointed out that the grouping into holocarpic and eucarpic is based on the conversion of thallus into reproductive structures. Since the thalli were not present in the infected patchouli, it is suggested to include $S$. pogostemonis infecting P. cablin in the holocarpic type.

The presence of prosorial and sorial stages prior to the sporangium formation is a clear indication that the $S$. pogostemonis has a long life-cycle. It implies the existence of a more complex process in the epidemic development of $S$. pogostemonis in the field, The strategy and approach of controlling $S$. pogostemonis might differ from those applied for potatoes, especially in exercising all efforts to erradicate the sources of inoculum in the soil and infected plant debris.

\section{REFERENCES}

Dayal M. 2007. Indian Chytridomycetes. M.D. New Delhi: Publications Pvt.

Hoffman Y, Aflalo C, Zarka A, Gutman J, James TY, Boussiba S. 2008. Isolation and characterization of a novel chytrid species (Phylum Blastocladiomycota), parasitic on the green alga Haematococcus. Mycol Res 112:70-81.

Karami A, Ahmad ZAM, Sijam K. 2009. Morphological characteristics and pathogenicity of Synchytrium psophocarpi (Rac.) Gäumann associated with false rust in winged bean. Am J Appl Sci 6: 1876-9.

Karling J. 1954. Host reaction, host-parasite relationship, hosts and taxonomic criteria in Synchytrium. Mycologia 46:292-313.

Karling J. 1964. Synchytrium. New York: Academic Pr.

Lange L, Olson LW. 1981. Development of the resting sporangia of Synchytrium endobioticum, the causal agent of potato wart disease. Protoplasma 106:83-95.

Garcia-Massini JL. 2007. A possible endoparasitic Chytridiomycetes fungus from the Permian of Antarctica. Palaeontol Electron 10:1-14.

Mustika I, Asman A. 2004. [Controlling insect pests and diseases of patchouli in Indonesia ] [in Indonesian].. Perkembangan Teknol Tan Rempah Obat 16:40-6.

Price TV. 1987. Liberation and germination of Synchytrium desmodii sporangia. Trans Br Mycol Soc 89:333-40.

Rao NNR, Pavgi MS. 1986. Acid-temperature-shock treatment as a method for inducing resting spore germination in some tropical synchytria. Curr Sci 55:196-7. 
Sitepu D, Asman A. 1991. [Research on diseases of patchouli in NAD]. [in Indonesian]. Laporan Kerja Sama Pupuk Iskandar Muda dan Balittro. $22 \mathrm{p}$.

Sukamto, Wahyuno D. 2008. Inokulasi jamur Synchytrium sp. pada tanaman nilam. Seminar nasional pengendalian terpadu OPT jahe dan nilam. Baliitro; 2008 Nov 4; Bogor, Indonesia. p147-52.

Thronton H. 2002. Synchytrium Bio-geography. http://bama.ua.edu/ rnsfpeet/Biogeography//Synchytrium Bio-geography [29 Oct 2010].
Wahyuno D. Sukamto. 2010. [The resistance of Pogostemon cablin and Pogostemon heyneanus against Synchytrium pogostemonis]. (in Indonesian). J Penel Tan Industri 16:91-7.

Wahyuno D, Sukamto, Manohara D, Kusnanta M.A, C. Sumardiyono C, Hartono S. 2007. Synchytrium a potential threat of patchouli in Indonesia. Proceeding international seminar on essential oil; $2007 \mathrm{Nov}$ 7-9; Jakarta: Indonesian Essential Oil Council. p 92-9.

Webster J. 1988. Introduction to fungi, $2^{\text {nd }}$ ed. Cambridge: Cambridge Univ Pr. 